\title{
Barbara Pędzich, Jak powstaje socjolekt? Studium słownictwa paralotniarzy, Wydawnictwa Uniwersytetu Warszawskiego, Warszawa 2012,
} ss. 290

Książka Barbary Pędzich pt. Jak powstaje socjolekt? Studium stownictwa paralotniarzy wpisuje się w nurt zainteresowań polskich lingwistów problematyką socjolektów osób uprawiających, zwłaszcza nieprofesjonalnie i na szeroką skalę, różne dyscypliny sportu. Przedmiotem rozprawy doktorskiej opublikowanej w postaci recenzowanej tu monografii autorka uczyniła język środowiska paralotniarzy. Opisała w niej sposoby gromadzenia i wzbogacania słownictwa oraz omówiła mechanizmy kształtowania się zasobu leksykalnego w zależności od pokrewnych wariantów języka polskiego oraz w relacji do języka ogólnego.

Praca składa się z dwóch części: teoretyczno-metodologicznej oraz materiałowej. Części właściwe zawierają wstępy oraz zakończenia z konkluzjami badawczymi. Na końcu książki zamieszczone są aneksy:

1) Leksyka paralotniarska $w$ ukladzie tematycznym,

2) Relacje semantyczne w leksyce paralotniarskiej,

3) Podziat jednostek wedlug opisanych mechanizmów ksztaltowania się leksyki,

4) Norma środowiskowa a norma polszczyzny ogólnej,

5) Wykaz zastosowanych w pracy skrótów i oznaczeń.

Dopełnienie pracy stanowi Stownik paralotniarski, będący osobną publikacją $^{1}$. Leksykon gromadzi korpus słownictwa i połączeń wyrazowych zebranych przez Pędzich podczas badań. Każdy artykuł hasłowy zawiera formę podstawową jednostki leksykalnej, definicję, kwalifikator, wymowę, informacje gramatyczne, dokumentację słownikową i etymologię, a także przykłady użycia (stąd brak tych informacji w recenzowanej pracy, w której autorka mogła bardziej skupić się na analizie).

\footnotetext{
${ }^{1}$ B. Pędzich, Stownik paralotniarski, Warszawa 2012.
} 
Celem rozprawy było ukazanie rozwoju badanej leksyki, dlatego Pędzich korzystała ze źródeł pochodzących z lat 1993-2009. Zebrany i zanalizowany materiał liczy 487 jednostek leksykalnych, w tym 393 leksemy oraz 93 „utrwalone połączenia wyrazowe" (frazeologizmy oraz zestawienia terminologiczne).

W początkowym rozdziale pierwszej części autorka przedstawiła stan badań nad socjolektami w Polsce. Omówiła tu naukowe dociekania nad odmianami związanymi z istnieniem różnego typu grup społecznych. Uwzględniła też dyskusję na temat stratyfikacji polszczyzny oraz problemów z terminologią (odmiana, wariant, język, gwara, żargon) i klasyfikacją socjolektów, na poparcie czego przedstawiła kilka typologii.

W drugim rozdziale zaprezentowano zasady paralotniarstwa, opisano krótko historię tego sportu oraz wyjaśniono, na czym polega specyfika środowiska paralotniarzy. Na uwagę zasługuje wykazana przez badaczkę znajomość owego środowiska i detali związanych z uprawianą przez nie dyscypliną, co widać m.in. we fragmencie, w którym zestawiła budowę paralotni z budową spadochronu.

Trzeci rozdział zawiera charakterystykę źródeł badawczych. Autorka wymieniła w nim źródła pisane (czasopisma, książki oraz strony internetowe) oraz mówione, opisane przez nią jako ,zasłyszane w typowych dla tego środowiska sytuacjach komunikacyjnych" (s. 37), czyli podczas kursów latania oraz spotkań pilotów w okolicznościach związanych z uprawianiem paralotniarstwa.

W czwartym rozdziale Pędzich sprecyzowała przedmiot i zakres badań; przyjęła, że „na zasób leksykalny [...] socjolektu składają się jednostki, które dotyczą realiów ściśle związanych z paralotniarstwem i które wyróżniają badany zasób słownictwa na tle innych odmian polszczyzny" (s. 43). Zainteresowania naukowe koncentrują się zarówno wokół specjalistycznej warstwy socjolektu, jak i elementów leksykalnych o charakterze środowiskowym.

Walorami książki są strukturalne uporządkowanie i opis zebranego materiału, którego autorka dokonała w obszernej części materiałowej. Szczegółowo zostały omówione wspomniane już wcześniej zapożyczenia wewnętrzne, a także jednostki leksykalne przejęte przez badany socjolekt $\mathrm{z}$ innych źródeł, czyli zapożyczenia zewnętrzne. Autorka zwraca uwagę na występowanie zapożyczeń z języka angielskiego (np. thumbling - 'obrót pilota tyłem wokół czaszy', lockout - 'duże odchylenie paralotni od kierunku startu') i niemieckiego (np. fulsztal - 'silne i równomierne zaciągnięcie sterówek, powodujące ułożenie czaszy w kształcie litery C', besztal - 'przeciągnięcie linek taśmami oznaczonymi literą B'), podkreślając, że te pierwsze zostały utrwalone w oryginalnej pisowni, drugie natomiast przyjmują formę spolszczoną. Poza leksemami związanymi ogólnie ze sportem (np. jazda, wspinać się) lub z poszczególnymi dyscyplinami pokrewnymi paralotniarstwu (np. spadochronowanie - 'niezamierzony stan lotu polegający na locie w dół, spowodowany błędem pilota 
lub nagłą zmianą kierunku wiatru, komora - 'przestrzeń między tymi żebrami czaszy, od których odchodzą linki nośne') te ostatnie obejmują też jednostki przejęte ze słownictwa młodzieżowego (np. padaka i kicha - 'warunki pogodowe, w których niemożliwe jest latanie paralotnią') oraz słownictwo i frazeologię pochodzące z języka ogólnego, ale funkcjonujące w nowych znaczeniach (np. kanapa w zn. 'paralotnia szkolna, przeznaczona dla niedoświadczonych, dopiero uczących się pilotów', gleba w zn. 'niezamierzone lądowanie, które nastąpiło mimo podejmowanych przez pilota prób utrzymania się w powietrzu'). Wśród nich badaczka wskazuje neosemantyzmy powstałe w wyniku 1) metafory (osobno omawiając metafory rzeczownikowe, np. goździk w zn. 'manewr ratowniczy stosowany w celu zwiększenia szybkości opadania, polegający na silnym ściągnięciu linek sterowniczych', przymiotnikowe, np. żywy $\mathrm{w}$ zn. 'łatwo reagujący na ruchy pilota' i czasownikowe, np. tańczyć w zn. 'kołysać się podczas lotu'), 2) metonimii (np. drzewo w zn. 'lądowanie na drzewie'), 3) zawężenia znaczenia (np. siedzisko w zn. 'dolna część uprzęży paralotniowej, będąca miejscem do siedzenia'), 4) aluzji formalno-semantycznej (np. latawiec w zn. 'paralotniarz').

W drugim rozdziale części materiałowej dokonano wnikliwej analizy jednostek leksykalnych utworzonych na gruncie socjolektu paralotniarskiego. Badaczka wyróżniła neologizmy słowotwórcze, a wśród nich konstrukcje: rzeczownikowe (np. szmatolotnictwo -'paralotniarstwo', wyczynówka - 'paralotnia wyczynowa', przelotowiec - 'paralotniarz specjalizujący się w przelotach'), przymiotnikowe (np. paraglidingowy - 'dotyczący paraglidingu', paralotni$c z y$ - 'dotyczący paralotnictwa', przelotowy - 'dotyczący przelotu, sprzyjający przelotom') i czasownikowe (np. przyklapić - 'o czaszy: zagiąć się podczas lotu', pofrunąć - 'lecąc, oddalić się od jakiegoś miejsca, polecieć, odlecieć', torbić - 'o nagłych zawirowaniach powietrza: rzucać, wstrząsać lecącą paralotnią, powodować, że czasza paralotni zaczyna trzepotać'), a także nowe struktury frazeologiczne (np. mistrz jednego pagóra - 'o pilocie paralotni', japoński slalom - 'konkurencja rozgrywana w zawodach paralotniarstwa silnikowego, w której zawodnik musi okrążyć wyznaczone terytorium w określonym czasie', zakładać krążenie 'po locie w określonym kierunku przechodzić do lotu ruchem kołowym') oraz nowe zestawienia terminologiczne (dotyczące technik startowania, np. start holowany, nazywające modele paralotni, np. paralotnia wyczynowa, dotyczące niebezpiecznych stanów lotu, np. podwinięcie czołowe).

Walorem pracy jest konsekwentne ukazanie mechanizmów powstawania socjolektu paralotniarzy i koncentracja na słownictwie, co zaznaczono w tytule oraz podkreślono we wstępie. Autorka jasno stwierdza, że skupia się na mechanizmach kształtowania się zasobu leksykalnego i określeniu, czy w tym procesie można wykryć jakiekolwiek prawidłowości. 
Aparat pojęciowy zastosowany w rozprawie, jak przyznaje sama autorka: „[...] wykorzystuje terminy tradycyjnego językoznawstwa stosowane w analizie leksyki" (s. 46). Sposób ich rozumienia badaczka modyfikuje na potrzeby pracy, dlatego podaje nieco zmienione klasyczne definicje jednostki leksykalnej, leksemu oraz jednostki nieciągłej (s. 47).

Na potrzeby pracy został też stworzony podział leksyki na dwie główne grupy: jednostki przejęte $\mathrm{z}$ innych źródeł $\mathrm{i}$ jednostki utworzone na gruncie nowej odmiany środowiskowej. Klasyfikacja zaproponowana przez Stanisława Grabiasa $^{2}$ została poszerzona m.in. o zapożyczenia wewnętrzne, co pozwoliło autorce uwzględnić zależności leksyki badanego socjolektu nie tylko od języka ogólnego, lecz także w zestawieniu ze słownictwem innych odmian środowiskowych. Pędzich w swej pracy pokusiła się o wskazanie zasobu słowno-frazeologicznego wspólnego dla socjolektu paralotniarzy i języka lotników (np. korkociag w zn. 'figura akrobacji lub niezamierzony stan lotu, polegający na opadaniu paralotni przy jednoczesnym obracaniu się wokół osi pionowej', spirala w zn. 'figura polegająca na wykonaniu serii bardzo ostrych zakrętów, stosowana w celu wytracenia wysokości', pętla w zn. 'pełny obrót boczny pilota ponad czaszą'), szybowników i lotniarzy (np. noszenie w zn. 'wstępujące prądy powietrza', żagiel w zn. 'obszar prądów zboczowych umożliwiający utrzymywanie się w powietrzu', przewianie w zn. 'przemieszczenie się paralotni na zawietrzną stronę zbocza, spowodowane silnym wiatrem') oraz spadochroniarzy (np. komora w zn. 'przestrzeń między tymi żebrami czaszy, od których odchodzą linki nośne', wlot w zn. 'każdy z otworów, przez które w czasie lotu do komór czaszy dostaje się powietrze', koperta w zn. 'rodzaj pokrowca na spadochron ratunkowy, przypominający kształtem kopertę'). Wymieniła też przykłady świadczące o istnieniu zasobu leksemów identycznego dla języka paralotniarzy oraz socjolektów osób uprawiających inne dziedziny sportu, takie jak: motoryzacja (np. poduszka powietrzna), narciarstwo (np. ośla łaczka), lekka atletyka (np. zając w zn. 'zawodnik forsujący tempo przez część dystansu w celu wyeliminowania słabszych zawodników'), gimnastyka (np. orczyk w zn. 'część paralotni służąca pilotowi do zwiększania prędkości'). Wspólny zasób leksemów został oczywiście poparty odpowiednimi cytatami, niemniej uznanie za pewnik tezy, że to jednostki socjolektu paralotniarskiego zostały przejęte odpowiednio z języka lotników, szybowników, lotniarzy, spadochroniarzy itp., wydaje się dość odważnym zabiegiem. Przyczyną takiego założenia jest - prawdopodobnie - moment narodzin paralotniarstwa, najmłodszej dyscypliny spośród wymienionych dziedzin sportu. W tym miejscu właściwe wydawałoby się jednak wskazanie sposobu badania zapożyczeń wewnętrznych

2 S. Grabias, Język w zachowaniach spolecznych, Lublin 1997. 
i możliwości odróżniania ich od zbieżnych efektów działania niezależnych w każdym socjolekcie mechanizmów nominacyjnych.

Materiał badawczy przytaczany w książce został zilustrowany odpowiednimi cytatami, pochodzącymi wprawdzie tylko ze źródeł internetowych, ale zarówno z elektronicznych wydań czasopism, jak i z dyskusji prowadzonych na forach internetowych czy też wpisów na blogach. Ciekawe uzupełnienie tych tekstów mogłyby stanowić przykłady transkrypcji naturalnych (oralnych) rozmów między paralotniarzami, uwzględnionych przecież podczas gromadzenia materiału.

W Zakończeniu, poza weryfikacją hipotez badawczych, autorka dokonuje krótkiej charakterystyki językowego obrazu świata paralotniarzy. Na podstawie opisanej leksyki stwierdza, że osoby uprawiające ten sport pozytywnie wartościują rzeczywistość.

Dostosowanie terminologii i klasyfikacji oraz szczegółowość analizy sprawiają, że książka Pędzich stanowi nie tylko wartościowe źródło wiedzy na temat języka paralotniarzy, lecz także wzór do prowadzenia badań nad innymi socjolektami sportowymi. 